\title{
Computing the carbonate chemistry of the coral calcifying medium and its
} response to ocean acidification

Virginie Raybaud $^{1,2,3,4}$, Sylvie Tambutté $e^{1,2}$, Christine Ferrier-Pagès ${ }^{1,2}$, Stéphanie Reynăud ${ }^{1,2}$, Alexander A. Venn ${ }^{1,2}$, Éric Tambutté ${ }^{1,2}$, Paul Nival $^{5}$, Denis Allemand ${ }^{1,}$

${ }^{1}$ Marine Biology Department, Centre Scientifique de Monaco, 8 Quai Antoine 1er, MC98000, Monaco.

${ }^{2}$ Laboratoire International Associé 647 «BIOSENSIB », Centre Scientifique de Monaco-Centre National de la Recherche Scientifique, 8 Quai Antoine 1er, MC98000, Monaco.

${ }^{3}$ Sorbonne Universités, UPMC Univ Paris 06, CNRS UMS 829, Observatoire Océanologique de Villefranchesur-Mer, 06230 Villefranche-sur-Mer, France

${ }^{4}$ Present address: Université Côte d'Azur, CNRS, ECOMERS, France

${ }^{5}$ Sorbonne Universités, UPMC Univ Paris 06, CNRS UMR 7093, Laboratoire d'Océanologie de Villefranche, 06230 Villefranche-sur-Mer, France.

Correspondence should be sent to:

virginie.raybaud@unice.fr; allemand@centrescientifique.mc 


\section{ABSTRACT}

Critical to determining vulnerability or resilience of reef corals to Ocean Acidification (OA) is a clearer understanding of the extent to which corals can control carbonate chemistry in their Extracellular Calcifying Medium (ECM) where the $\mathrm{CaCO}_{3}$ skeleton is produced. Here, we employ a mathematical framework to calculate ECM aragonite saturation state $\left(\Omega_{\text {arag.(ECM) }}\right.$ and carbonate system ion concentration using measurements of calcification rate, seawater characteristics (temperature, salinity and $\mathrm{pH})$ and $\mathrm{ECM} \mathrm{pH}\left(\mathrm{pH}_{(\mathrm{ECM})}\right)$ ). Our calculations of ECM carbonate chemistry at current-day seawater $\mathrm{pH}$, indicate that $\Omega_{\mathrm{arag} .(\mathrm{ECM})}$ ranges from $\sim 10$ to 38 (mean 20.41), i.e. about 5 to 6-fold higher than seawater. Accordingly, Dissolved Inorganic Carbon (DIC) and Total Alkalinity (TA) were calculated to be around 3 times higher in the ECM than in seawater. We also assessed the effects of acidification on ECM chemical properties of the coral Stylophora pistillata. At reduced seawater $\mathrm{pH}$ our calculations indicate that $\Omega_{\text {arag.(ECM) }}$ remains almost constant. $\mathrm{DIC}_{(\mathrm{ECM})}$ and $\mathrm{TA}_{(\mathrm{ECM})}$ gradually increase as seawater $\mathrm{pH}$ declines, reaching values about 5 to 6-fold higher than in seawater, respectively for DIC and TA. We propose that these ECM characteristics buffer the effect of acidification and explain why certain corals continue to produce $\mathrm{CaCO}_{3}$ even when seawater chemistry is less favourable.

Keywords: Scleractinian Corals; Calcification; Calcifying Fluid; Aragonite Saturation State; Ocean Acidification. 


\section{Introduction}

Calcification by scleractinian corals is responsible for the world's most prominent biomineral constructions, coral reefs. Although coral reefs cover less than $0.2 \%$ of the world's ocean (Spalding et al., 2001), they offer a habitat for approximately one third of known marine species (Porter and Tougas, 2001) and provide an estimated US\$30 billion annually in ecosystem goods and services (Moberg and Folke, 1999). Currently, coral reefs are faced with many anthropogenic threats, both at global scales (e.g. Ocean Acidification (OA) and warming) and regional scales (e.g. pollution, habitat destruction, over-fishing, eutrophication).

Corals precipitate calcium carbonate (as the polymorph of aragonite) to form their skeletons, a process which is sensitive to OA. Although the response of different coral species may vary and many aspects of how coral reefs respond to OA remain poorly understood, meta-analysis of published data indicates that generally ocean acidification has a deleterious effect on coral calcification rates (Chan and Connolly, 2013). Coral skeletons do not grow in direct contact with the surrounding seawater, however, but actually under the coral tissue in an Extracellular Calcifying Medium (ECM), located at the interface between the calcifying cells and the underlying skeleton surface. Knowledge of the chemical composition of the ECM at this interface is crucial to understanding how changes in the chemical properties of the external seawater drive changes in coral calcification. However, available information about the coral ECM remains limited, partly because it is difficult to access under several overlying cell layers and because its thickness varies from just a few nanometers to a few micrometers (Tambutté et al., 2011). Only a few studies concern either direct (Al-Horani et al., 2003; Cai et al., 2016; Kühl et al., 1995; Ries, 2011; Venn et al., 2011; Venn et al., 2013) or indirect (Dissard et al., 2012; Holcomb et al., 2014; Hönisch et al., 2004; Krief et al., 2010; McCulloch et al., 2012a; Reynaud et al., 2004; Trotter et al., 2011) 
measurements of chemical parameters in the ECM and results show that ECM composition differs from seawater, suggesting a biological control by corals. Whereas most of the above studies focused on assessing ECM pH, only two gave values of calcium (Al-Horani et al., 2003) and carbonate (Cai et al., 2016) concentrations. Carbonate ion concentrations together with $\mathrm{pH}$ inside corals have been recently measured for the first time using microelectrodes on three scleractinian coral species (Cai et al., 2016). However, due to experimental difficulties to reach the ECM, measurements of two parameters of the carbonate system remains scarce. This knowledge gap precludes a clear understanding of the effect of OA on calcification.

Two methods of indirect assessment of ECM chemical composition have therefore been proposed in the literature (Allison et al., 2014; McCulloch et al., 2012a). McCulloch and colleagues used a modelling approach (IpHRAC model) which is based on the assumption that $[\mathrm{DIC}]_{(\mathrm{ECM})}=2 \mathrm{x}[\mathrm{DIC}]_{(\mathrm{SW})}$, where $\mathrm{sw}$ refers to seawater (McCulloch et al., 2012a). Aragonite saturation state in the $\operatorname{ECM}\left(\Omega_{\text {arag. }(\mathrm{ECM})}\right)$ is then calculated from $[\mathrm{DIC}]_{(\mathrm{ECM})}, \mathrm{pH}_{(\mathrm{ECM})}$ and $\left[\mathrm{Ca}^{2+}\right]_{(\mathrm{ECM})}$ and coral calcification rate is therefore deduced from $\Omega_{\text {arag.(ECM). }}$ In the study of Allison and colleagues, ECM composition was assessed from skeletal boron geochemistry (Allison et al., 2014). As it is unclear if both bicarbonate and carbonate are utilised during aragonite precipitation, they used $\mathrm{B}(\mathrm{OH})_{4}{ }^{-} / \mathrm{CO}_{3}{ }^{2-}, \mathrm{B}(\mathrm{OH})_{4}{ }^{-} / \mathrm{HCO}_{3}{ }^{-}$and $\mathrm{B}(\mathrm{OH})_{4}{ }^{-} /\left(\mathrm{CO}_{3}{ }^{2-}+\right.$ $\mathrm{HCO}_{3}{ }^{-}$) aragonite partition coefficients from $\delta^{11} \mathrm{~B}$ and $\mathrm{pH}_{(\mathrm{ECM})}$ to estimate all the other parameters in the ECM DIC system.

Here we present a novel, alternative means of indirectly assessing ECM carbonate chemistry using coral calcification rates, seawater characteristics (temperature, salinity and $\mathrm{pH})$ and $\mathrm{pH}$ measurements of the $\mathrm{ECM}\left(\mathrm{pH}_{(\mathrm{ECM})}\right)$. The robustness of this approach relies on the fact that our series of calculations is not based on an assumption of $[\mathrm{DIC}]_{(\mathrm{ECM})}$, but rather on empirical data. Furthermore, our approach has the advantage of using calcification rate, which is among the most widely used and easily measured physiological parameter for corals, 
and for which a large reservoir of data is available in the literature on which to base our calculations.

Only two carbonate chemistry variables are needed to calculate concentrations of the other ions in the carbonate system. Here we used species-specific estimations of $\mathrm{pH}_{(\mathrm{ECM})}$ (derived from seawater $\mathrm{pH}$ ) and $\left[\mathrm{CO}_{3}{ }^{2-}\right]_{(\mathrm{ECM})}$ (determined from calcification rate) to calculate all the other parameters of the carbonate system. As there are few measurements of $\mathrm{pH}_{(\mathrm{ECM})}$ relative to calcification measurements available in the literature, we first present a speciesspecific method to calculate $\mathrm{pH}_{(\mathrm{ECM})}$ from seawater $\mathrm{pH}$ when it has not been experimentally measured. Secondly, we use coral calcification rates to calculate $\Omega_{\text {arag.(ECM) }}$ and $\left[\mathrm{CO}_{3}{ }^{2-}\right]_{(\mathrm{ECM})}$. Thirdly, we used $\mathrm{pH}_{(\mathrm{ECM})}$ and $\left[\mathrm{CO}_{3}{ }^{2-}\right]_{(\mathrm{ECM})}$ to calculate the ionic concentration of the other chemical species of the carbonate system in the ECM. A comprehensive scheme summarising the different steps of our approach is given in Fig. 1.

We applied this series of calculations on 29 calcification rates retrieved from the literature (from cold-water corals to tropical species) in order to evaluate the range of chemical conditions under which coral skeletons are formed under current environmental seawater conditions. Additionally, we go on to evaluate how partial-pressure $\mathrm{CO}_{2}$-driven seawater acidification influences ECM characteristics. Insight into the extent to which corals modify their ECM composition in response to OA will help inform models of coral calcification (Hohn and Merico, 2012; Nakamura et al., 2013) and improve biogeochemical models (Alekseenko et al., 2014; Gehlen et al., 2014; Raybaud et al., 2011) in making predictions for the fate of coral reefs in the $21^{\text {st }}$ century and beyond. 


\section{Methods}

\subsection{Origin of Extracellular Calcifying Medium pH data and statistical analysis}

We compiled $\mathrm{pH}_{(\mathrm{ECM})}$ data from six studies on 5 different species in the literature that have measured $\mathrm{pH}_{(\mathrm{ECM})}$ at several different levels of seawater $\mathrm{pH}$. As these studies include $\mathrm{pH}_{(\mathrm{ECM})}$ data over a range of seawater $\mathrm{pH}$ values, we considered that these studies were the most informative for assessing the $\mathrm{pH}_{(\mathrm{ECM})}$ and seawater $\mathrm{pH}$ relationship. Using these studies, we calculated species-specific linear regressions between seawater $\mathrm{pH}$ and $\mathrm{pH}_{(\mathrm{ECM})}$ for: Desmophyllum dianthus, Cladocora caespitosa, Porites spp., Acropora spp. and Stylophora pistillata. The data include $\mathrm{pH}_{(\mathrm{ECM})}$ measurements derived from boron isotope analysis and direct $\mathrm{pH}_{(\mathrm{ECM})}$ measurements by confocal microscopy. $\mathrm{pH}_{(\mathrm{ECM})}$ data for S. pistillata were more widely spread than the other species. We conducted two regressions for the S. pistillata data, one for the boron isotope measurements of $\mathrm{pH}_{(\mathrm{ECM})}$ and one for the confocal measurements of $\mathrm{pH}_{(\mathrm{ECM})}$.

We used these relationships between seawater $\mathrm{pH}$ and $\mathrm{pH}_{(\mathrm{ECM})}$ in the rest of the manuscript to determine $\mathrm{pH}_{(\mathrm{ECM})}$ in studies listed in Supplementary Table $\mathrm{S} 1$ with the aim to calculate the corresponding ECM chemical composition. This analysis included the use of both $\mathrm{pH}_{(\mathrm{ECM})}$ regressions generated for S. pistillata.

$\mathrm{pH}_{(\mathrm{ECM})}$ data were transformed to $\left[\mathrm{H}^{+}\right]_{(\mathrm{ECM})}$ according to the formula:

$\left[\mathrm{H}^{+}\right]_{(\mathrm{ECM})}=10^{-\mathrm{pH}_{(\mathrm{ECM})}}$

All $\mathrm{pH}$ values are expressed in total scale. When $\mathrm{pH}$ measurements were given on NBS scale, we converted $\mathrm{pH}$ data to total scale using VB-scripts ' $\mathrm{pH} \_$nbs2total' provided by MBARI (available at: http://www.mbari.org/products/research-software/visual-basic-for-exceloceanographic-calculations/). 


\subsection{Origin of the calcification rates}

We compiled 29 coral calcification rates (normalized to the corals' surface area) and seawater characteristics (temperature, salinity, $\mathrm{pH}$ ) from 20 peer-reviewed publications (listed in Supplementary Table S1) to calculate the corresponding values of $\Omega_{\text {ara.(ECM) }}$ and the carbonate chemistry composition of the ECM. We restricted our data compilation to studies for which species-specific linear regressions between seawater $\mathrm{pH}$ and $\mathrm{pH}_{(\mathrm{ECM})}$ has been established (see paragraph 2.1). We considered only laboratory experiments under controlled environmental conditions, i.e. no field studies. We retrieved only the calcification rates of control treatment (i.e. optimal light and food) or present-day conditions (gurrent seawater $\mathrm{pH}$, $\mathrm{pCO}_{2}$ and $\left.\Omega_{(\mathrm{sw})}\right)$ with the aim to calculate the composition of the calcifying fluid corresponding to optimal or current conditions. When full carbonate chemistry was not available directly from the publications or when variables were reported in different units, we calculated carbonate chemistry using the relevant data deposited for the respective publication in the OA-ICC (Ocean Acidification International Coordination Centre; http://www.iaea.org/ocean-acidification/page.php?page=2195) database (Nisumaa et al., 2010). Although our list of coralcalcification rates normalized to surface area is not exhaustive, the high number of values $(\mathrm{N}=29)$ enabled us to evaluate the range of ECM compositions on a wide range of corals, from cold-water species (which have a slow growth rate) to tropical corals (which grow faster).

Since the 29 calcification rates used here were measured using two different experimental techniques (total alkalinity anomaly and buoyant weight), we verified the adequacy between measurements before using them. A graphical representation of mean and standard deviation of calcification rates measured using the 2 methods is presented in Supplementary figure S2. Supplementary Table 1 indicates which studies used which 
method. A one-way ANOVA revealed no significant difference between calcification rates assessed with the two techniques $\left(\mathrm{F}_{1,27}=2.86, \mathrm{p}>0.05\right)$.

\subsection{Calculation of the ECM aragonite saturation state $\left(\Omega_{\text {arag.(ECM) }}\right)$}

The relationship between calcification rate $\left(\mathrm{G}\right.$, in $\left.\mu \mathrm{mol} \cdot \mathrm{m}^{-2} \cdot \mathrm{h}^{-1}\right)$ and ECM aragonite saturation state $\left(\Omega_{\text {arag.(ECM) }}\right)$ is described by the empirical exponential rate dependence law of aragonite precipitation (Burton and Walter, 1987; Mucci and Morse, 1983):

$\mathrm{G}=\mathrm{k}_{\mathrm{p}} \cdot\left(\Omega_{\text {arag.(ECM })}-1\right)^{\mathrm{n}}$

where $\mathrm{k}_{\mathrm{p}}$ and $\mathrm{n}$ are temperature-dependent parameters (McCulloch et al., 2012a)

$k_{p(T)}=-0.0177 \mathrm{~T}^{2}+1.47 \mathrm{~T}+14.9$

$n_{(T)}=0.0628 \mathrm{~T}+0.0985$

with $\mathrm{T}$, the temperature (expressed in ${ }^{\circ} \mathrm{C}$ ).

Using a logarithmic transformation, $\Omega_{\text {arag.(ECM) }}$ can be deduced from Eq. 2 :

$\Omega_{\text {arag.(ECM) }}=1+\exp \left[\frac{\left[\left(\log (\mathrm{G})-\log \left(\mathrm{k}_{\mathrm{p}}\right)\right] \cdot \ln (10)\right.}{\mathrm{n}}\right]$

\subsection{Calculations of ECM carbonate ion concentration}

$\Omega_{\text {arag.(ECM) is also represented by the product of calcium and carbonate ion }}$ concentrations (in mol. $\mathrm{kg}^{-1}$ ) divided by the solubility product of aragonite $\left(\mathrm{k}_{\mathrm{spa}}\right)$ :

$\Omega_{\text {arag.(ECM) }}=\frac{\left[\mathrm{Ca}^{2+}\right]_{(\mathrm{ECM})}\left[\mathrm{CO}_{3}{ }^{2-}\right]_{(\mathrm{ECM})}}{\mathrm{k}_{\mathrm{spa}}}$

The solubility product of aragonite $\left(\mathrm{k}_{\mathrm{spa}}\right)$ depends both on temperature $(\mathrm{T})$ and salinity $(\mathrm{S})$

(Mucci, 1983; Zeebe and Wolf-Gladrow, 2001):

$k_{\text {spa }}=10^{\left(-171.95-0.08 \mathrm{~T}+\frac{2903.293}{\mathrm{~T}}+71.60 * \log (\mathrm{T})+\left(-0.07+0.002 \mathrm{~T}+\frac{88.14}{\mathrm{~T}}\right) * \sqrt{\mathrm{S}}-0.10 \mathrm{~S}+0.006 * \mathrm{~S}^{1.5}\right)}$

As $\Omega_{\text {arag.(ECM) }}$ can be estimated using equation 6, we can deduce ECM carbonate ion concentration by transforming equation 7 as follows: 


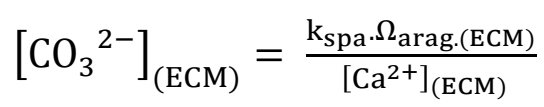

As $\left[\mathrm{Ca}^{2+}\right]_{(\mathrm{ECM})}$ has never been measured in S. pistillata, we used the approximation published by McCulloch and colleagues (McCulloch et al., 2012a), based on Al-Horani et al., (2003) measurements performed on Galaxea fascicularis: $\left[\mathrm{Ca}^{2+}\right]_{(\mathrm{ECM})}=\left[\mathrm{Ca}^{2+}\right]_{(\mathrm{SW})}+0.5$ $\left(\mathrm{mmol} . \mathrm{kg}^{-1}\right)$ where sw refers to seawater values. For tropical seawater, we used $\left[\mathrm{Ca}^{2+}\right]_{(\mathrm{SW})}=10$ mmol. $\mathrm{kg}^{-1}$ and $\left[\mathrm{Ca}^{2+}\right]_{(\mathrm{SW})}=11.2 \mathrm{mmol} . \mathrm{kg}^{-1}$ for the Mediterranean sea (McCulloch et al., 2012a). As Al-Horani et al. (2003) showed that $\left[\mathrm{Ca}^{2+}\right]_{(\mathrm{ECM})}$ varies over time, especially with light, we performed a sensitivity analysis on the calculated ECM composition related to the $\left[\mathrm{Ca}^{2+}\right]_{(\mathrm{ECM})}$ estimation to evaluate how the uncertainty of $\left[\mathrm{Ca}^{2+}\right]_{(\mathrm{ECM})}$ could propagate through the series of calculations and affect our results (see Supplementary Fig. S2). This analysis showed that the sensitivity of calculated ECM composition to the estimated $\left[\mathrm{Ca}^{2+}\right]_{(\mathrm{ECM})}$ was low $(<8 \%)$.

\subsection{ECM carbonate chemistry composition}

The seawater carbonate chemistry is constrained by well-known thermodynamic equilibria allowing all components of this system to be calculated from only two variables. In this study, we used $\mathrm{pH}_{(\mathrm{ECM})}$ and $\left[\mathrm{CO}_{3}^{2-}\right]_{(\mathrm{ECM})}$ to compute all other components of the carbonate system in the $\mathrm{ECM}\left(\left[\mathrm{HCO}_{3}^{-}\right]_{(\mathrm{ECM})},\left[\mathrm{CO}_{2}\right]_{(\mathrm{ECM})},\left[\mathrm{OH}^{-}\right]_{(\mathrm{ECM})}, \mathrm{DIC}_{(\mathrm{ECM})}\right.$ and $\mathrm{TA}_{(\mathrm{ECM})} ;$ Fig. 1). Here, we used the carbonate chemistry package "csys.m" (Zeebe and Wolf-Gladrow, 2001), using constants from Mehrbach et al. (Mehrbach et al., 1973) as refit by Dickson and Millero (Dickson and Millero, 1987). We used csys.m version updated on Apr 2014 (i.e the latest available version on Jan 2017). In csys.m, concentration of boron ( $\mathrm{mol} / \mathrm{kg}$ ) and total sulfate $(\mathrm{mol} / \mathrm{kg}$ ) are varying with salinity, using the following formulas (Zeebe and Wolf-Gladrow, 2001):

$\left[\mathrm{B}(\mathrm{OH})_{4}{ }^{-}\right]=1 .^{*}(415.7 *(\mathrm{~S} / 35)). * 10^{-6}$ 
$\left[\mathrm{TSO}_{4}\right]=0.14 / 96.062 / 1.80655 * \mathrm{~S}$

with S, the salinity.

Note that silicate is not taken into account.

Equilibrium constants were calculated using equic.m, a program provided with csys.m, which calculates $\mathrm{CO}_{2}$ equilibrium constants, with equations from Dickson and Goyet (1994).

A comprehensive scheme summarising the different steps to calculate the carbonate chemistry composition of the coral ECM from calcification rate and seawater characteristics is given in Fig. 1.

\subsection{Errors estimation and propagation along the calculation chain}

In laboratory experiments, physiological parameters measurements (such as calcification rates and $\left.\mathrm{pH}_{(\mathrm{ECM})}\right)$ includes several replicates and results are generally presented as mean \pm standard error. As calcification rates and $\mathrm{pH}_{(\mathrm{ECM})}$ regressions are both based on experimental measurements, it is very interesting to analyze how experimental errors propagate along the calculation chain and influence the final results (i.e ECM composition). For this analysis, we considered a virtual tropical coral with a calcification rate of $\mathrm{G}=6000 \mu \mathrm{mol} \cdot \mathrm{m}^{-2} \cdot \mathrm{h}^{-1}$ and a $\mathrm{pH}_{(\mathrm{ECM})}$ value of 8.4 (typical values for a tropical coral growing at seawater $\mathrm{pH}$ of 8.0 ).

First, we varied calcification rate alone to quantify how final results (ECM composition) changed. We calculated ECM composition with (1) G=6000 $\mu \mathrm{mol} \cdot \mathrm{m}^{-2} \cdot \mathrm{h}^{-1}$ (reference value), (2) $\mathrm{G}-3 \%$ (i.e $5820 \mu \mathrm{mol} \cdot \mathrm{m}^{-2} \cdot \mathrm{h}^{-1}$ ) and (3) $\mathrm{G}+3 \%$ (i.e $6180 \mu \mathrm{mol} \cdot \mathrm{m}^{-2} \cdot \mathrm{h}^{-1}$ ). In all cases, the value of $\mathrm{pH}_{(\mathrm{ECM})}$ was left at 8.40 and environmental parameters were set at $\mathrm{T}=25^{\circ} \mathrm{C}, \mathrm{S}=35$. We have chosen to add or subtract $3 \%$ to calcification rates because this value 
encompasses the maximum standard error in measurements recorded in Tambutté et al. (2015).

Second, we varied $\mathrm{pH}_{(\mathrm{ECM})}$ alone to quantify how final results were affected. We calculated the maximum error on estimating $\mathrm{pH}_{(\mathrm{ECM})}$ from seawater $\mathrm{pH}$ using regressions (cf Fig. 2): $0.13 \mathrm{pH}$ unit. We therefore computed $\mathrm{ECM}$ composition with (1) $\mathrm{pH}_{(\mathrm{ECM})}=8.4$ (reference value), (2) $\mathrm{pH}_{(\mathrm{ECM})}=8.4-0.13$ (i.e 8.27) and (3) $\mathrm{pH}_{(\mathrm{ECM})}=8.4+0.13$ (i.e 8.53). For these calculations, calcification rate was set at $\mathrm{G}=6000 \mu \mathrm{mol} \cdot \mathrm{m}^{-2} \cdot \mathrm{h}^{-1}$ and temperature and salinity were set respectively at $25^{\circ} \mathrm{C}$ and 35 .

Finally, we varied both calcification rate and $\mathrm{pH}_{(\mathrm{ECM})}$ to quantify the combined effect of errors on the final result. We calculated the ECM composition with (1) G-3\% and $\mathrm{pH}_{(\mathrm{ECM})}+0.13$, (2) $\mathrm{G}-3 \%$ and $\mathrm{pH}_{(\mathrm{ECM})}-0.13$, (3) $\mathrm{G}+3 \%$ and $\mathrm{pH}_{(\mathrm{ECM})}+0.13$, (4) $\mathrm{G}+3 \%$ and $\mathrm{pH}_{(\mathrm{ECM})}-0.13 . "$

\subsection{Assessment of ECM characteristics under seawater acidification}

We examined the effect of seawater acidification on ECM characteristics by using coral calcification rates and $\mathrm{pH}_{(\mathrm{ECM})}$ from a long-term experiment where colonies of $S$. pistillata were exposed to different seawater acidification conditions for more than 1 year. During this experiment, the carbonate chemistry of seawater was manipulated by bubbling $\mathrm{CO}_{2}$ to reduce $\mathrm{pH}$ in four aquaria (seawater $\mathrm{pH}=7.2,7.4,7.8$ and 8.0). A full description of the experimental design can be found in (Venn et al., 2013) and (Tambutté et al., 2015). In this study, we used calcification rates measured for each $\mathrm{pH}$ treatment and ECM pH directly measured with confocal microscopy to calculate the corresponding chemical composition of ECM under seawater acidification. 


\section{Results and discussion}

\section{1 pH in the Extracellular Calcifying Medium}

Figure 2 displays the regressions of $\mathrm{pH}_{(\mathrm{ECM})}$ data in five species taken from six publications. This data compilation shows, for all species, an up-regulation of $\mathrm{pH}_{(\mathrm{ECM})}$ compared with seawater $\mathrm{pH}$ and a decline of $\mathrm{pH}_{(\mathrm{ECM})}$ with seawater acidification. Moreover, the up-regulation of $\mathrm{pH}_{(\mathrm{ECM})}$ appears higher when seawater $\mathrm{pH}$ is low, indicating an active biological control of the ECM chemistry by corals.

At current seawater $\mathrm{pH}(8.0-8.1)$, cold-water scleractinian corals exhibit the strongest up-regulation of $\mathrm{pH}_{(\mathrm{ECM})}$ (Anagnostou et al., 2012; McCulloch et al., 2012b), followed by temperate species such as Cladocora caespitosa and by tropical species (e.g Porites spp., Acropora spp. and S. pistillata; Fig. 2). Our representation also highlights the lack of data for temperate and cold-water corals in low $\mathrm{pH}$ conditions (seawater $\mathrm{pH}<7.6$ ).

The species included in the analysis were those where $\mathrm{pH}_{(\mathrm{ECM})}$ had been determined at a number of different seawater $\mathrm{pH}$ values. Equations of linear regressions are given in Fig. 2. These equations are used for the determination of ECM chemistry in the studies listed in Supplementary table $\mathrm{S} 1$. It is important to highlight the fact that these $\mathrm{pH}_{(\mathrm{ECM})}$ data come from field studies (derived from boron isotope measurements) as well as lab studies (derived from both boron isotope and confocal measurements). It would have been preferable to use data exclusively from lab studies, as we have done in the case of the calcification data, because environmental parameters (with which the $\mathrm{pH}_{(\mathrm{ECM})}$ data are associated), are more variable in 
the field than the lab, and more difficult to accurately constrain with monitoring and measurements. Furthermore, due to environmental variation, potentially large intraspecific differences in calcification rate and other physiological processes could be observed between the field and lab culture studies. Due to the restricted number of published $\mathrm{pH}_{(\mathrm{ECM})}$ measurements available in the literature (particularly for deep water corals) we had to use all available data.

It is also important to note that we plotted two $\mathrm{pH}_{(\mathrm{ECM})}$ regressions for Stylophora pistillata, one for the boron isotope analysis and one for the confocal analysis (Figure 2). While the slopes of both regressions are similar, the absolute values of $\mathrm{pH}_{(\mathrm{ECM})}$ determined by confocal measurements fall below those determined by boron isotope analysis. One issue explaining this difference could be that boron isotope measurements represent an integrated signal of both day and night time $\mathrm{pH}$, whereas all the confocal measurements were conducted in the light. This is unlikely to be the case, however, because $\mathrm{pH}_{(\mathrm{ECM})}$ increases in the light relative to dark (Venn et al.2011), and in Figure 2 it is apparent that confocal $\mathrm{pH}_{(\mathrm{ECM})}$ values obtained in the light are actually lower than the boron isotope measurements. Holcomb et al. (2014) carried out both techniques on the same coral samples and attributed the difference to spatial differences in coral $\mathrm{pH}_{(\mathrm{ECM})}$ regulation under seawater acidification. Indeed, the results of Holcomb et a1. (2014) indicate that in S. pistillata, $\mathrm{pH}_{(\mathrm{ECM})}$ levels are highest at the coral apex and lowest at the edge of lateral growth, the latter location being where confocal measurements are carried out. In any case, to investigate the effect of the different regressions drawn on the $S$. pistillata data, we included both regressions in calculations of ECM carbonate chemistry carried out later in this investigation (Figure 4 and Supplementary Fig. S3).

\subsection{Aragonite saturation state in the ECM}


The second parameter we used for the determination of ECM chemistry was

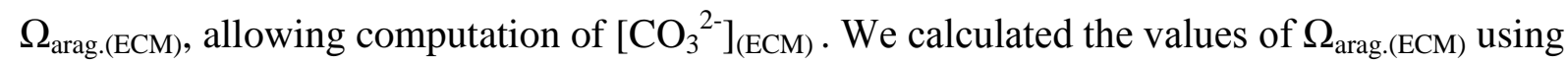
equation (5) (see Methods) from 29 coral calcification rates retrieved from 20 publications (listed in Supplementary Table S1) and we report $\Omega_{\text {arag.(ECM) values as a function of }}$ calcification rates and seawater temperature (Fig. 3A). Although each coral species is characterized by a unique thermal niche (Jokiel and Coles, 1977; Rodolfo-Metalpa et al., 2006) (i.e. the range of temperatures where species can survive, grow and reproduce), when we considered all species together (from cold-water to tropical corals), coral calcífication rates exponentially increased with temperature (Fig. 3A). This result is in agreement with Arrhenius' law which describes exponential increase of reaction rates with temperature (Arrhenius, 1889). This positive relationship between calcification rates and temperature has already been reported in numerous studies (Bessat and Buigues, 2001; Coles and Jokiel, 1977; McNeil et al., 2004; Reynaud-Vaganay et al.,1999; Silverman et al., 2007) but our work also provides, for the first time, the corresponding value of $\Omega_{\text {arag.(ECM) }}$ of each of these studies. The mean $\Omega_{\text {arag.(ECM) }}$ based on the 20 studies analysed was 20.41 but values ranged from 10.16 to 38.31 , with a median value of 18.26 (Fig. $3 \mathrm{~B}$ ). On average, $\Omega_{\text {arag.(ECM) was }} \sim 5$ to 6 -fold higher

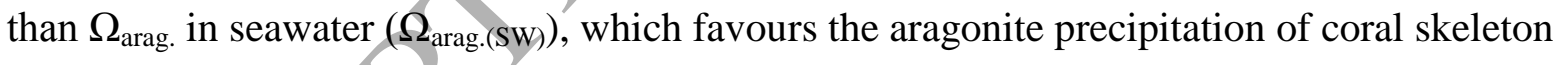
in the ECM. A negative relationship was found between $\Omega_{\text {arag.(ECM) }}$ and seawater temperature (Fig. $\left.3 C ; y=-1.00 x+43.03, r^{2}=0.42, p<0.05\right) . \Omega_{\text {arag. (ECM) }}$ was higher for cold-water corals, which have slower growth rates than for tropical ones. The greater ability of certain coldwater coral species to raise their $\Omega_{\text {arag.(ECM) }}$ may be an adaptive mechanism, as recently suggested by Hendriks and colleagues (Hendriks et al., 2015), enabling these organisms to grow in seawater that is close to under-saturation with respect to aragonite $\left(\Omega_{\text {arag.(SW) }} \sim\right.$; (Thresher et al., 2011)). 
Our results are consistent with the range of $\Omega_{\text {arag.(ECM) }}$ values $\left(\Omega_{\text {arag.(ECM) }}=11-19\right)$ recently assessed from skeletal isotopic boron composition of Porites spp. field corals by Allison and colleagues (Allison et al., 2014), but we show that $\Omega_{\text {arag.(ECM) }}$ may also be higher than 19 (we found here a maximum value of 38.31). The range of $\Omega_{\text {arag.(ECM) }}$ calculated here also encompasses the range of $\Omega_{\text {arag.(ECM) }}$ estimated by IpHRAC model (Internal $\mathrm{pH}$ Regulation with Abiotic Calcification), in which the authors found that $\Omega_{\text {arag.(ECM) }}$ varied between $\sim 15$ and $~ 25$ (McCulloch et al., 2012a).

Our assessment of $\Omega_{\text {arag.(ECM) }}$ is based on equation (5) and varies as a function of calcification rate and temperature. In other terms, we calculated the saturation state required in the ECM to sustain the measured calcification rate, under the assumption that the relationship between saturation state and precipitation rate is the same in corals and in inorganic aragonite. Note that this assumption divides the scientific community. On one hand, Allison and colleagues consider this relationship very different in corals compared to inorganic aragonite (Allison et al., 2014). On the other hand, McCulloch and colleagues based their study on the assumption that the relationship established for inorganic aragonite remains available for biogenic precipitation in corals (McCulloch et al., 2012a). Although the literature is divided about the kinetic parameters for aragonite precipitation rates in corals, all studies agree to show that ECM composition greatly differs from seawater, which highlights an active biological control by corals performed through ions transporters (Zoccola et al., 2015).

\subsection{ECM chemical composition under current seawater pH}

We calculated the concentrations of $\mathrm{CO}_{3}{ }^{2-}$ in the ECM from $\Omega_{\text {arag.(ECM) }}$ using equation (8) and we plotted mean $\left[\mathrm{CO}_{3}{ }^{2-}\right]_{(\mathrm{ECM})}$ and standard deviation, based on the 29 calcification 
rates considered here (Fig. 4). Results showed that ECM carbonate concentration ranged from 1067 to $1911 \mu$ mol.kg ${ }^{-1}$, with a mean of $1400 \mu$ mol.kg-1 , a value on average 5.9 times higher than in seawater. The cold-water coral Desmophyllum dianthus presents the highest value of $\left[\mathrm{CO}_{3}{ }^{2-}\right]_{(\mathrm{ECM})}$, followed by the temperate coral Cladocora caespitosa, then followed by tropical species (Stylophora pistillata, Acropora spp. and Porites spp.). These findings suggest that corals elevate $\mathrm{CO}_{3}{ }^{2-}$ in the ECM to facilitate $\mathrm{CaCO}_{3}$ precipitation. Our $\left[\mathrm{CO}_{3}{ }^{2-}\right]$ values are consistent with recent direct $\left[\mathrm{CO}_{3}{ }^{2-}\right]_{(\mathrm{ECM})}$ measurements using microelectrodes (Cai et al., 2016) on Turbinaria reniformis $\left(\left[\mathrm{CO}_{3}{ }^{2-}\right]_{(\mathrm{ECM})} \approx 1000-1400 \mu \mathrm{mol} . \mathrm{kg}^{-1}\right)$, Acropora millepora $\left(\left[\mathrm{CO}_{3}{ }^{2-}\right]_{(\mathrm{ECM})} \approx 1500 \mu \mathrm{mol} . \mathrm{kg}^{-1}\right)$ and Orbicella faveolata $\left(\left[\mathrm{CO}_{3}{ }^{2-}\right]_{(\mathrm{ECM})} \approx 600 \mu \mathrm{mol} . \mathrm{kg}^{-1}\right)$.

Having established $\left[\mathrm{CO}_{3}{ }^{2-}\right]_{(\mathrm{ECM})}$, we were able to use this value with $\mathrm{pH}_{(\mathrm{ECM})}$ to calculate the concentration of all other variables of the carbonate system in the ECM. We found bicarbonate ions were on average 2.1 times more concentrated in the ECM compared to seawater (Fig. 4; mean $\left[\mathrm{HCO}_{3}^{-}\right]_{(\mathrm{ECM})}=3806 \mu$ mol.kg ${ }^{-1}$ ), $\left[\mathrm{OH}^{-}\right]_{(\mathrm{ECM})}$ was also 2.3 fold higher, while $\mathrm{CO}_{2}$ concentrations were in the same order of magnitude in ECM and ambient seawater. $\mathrm{DIC}_{(\mathrm{ECM})}$ and $\mathrm{TA}_{(\mathrm{ECM})}$ were found to be around 3 times higher than in seawater, reaching on average 5214 and $6830 \mu$ mol. $\mathrm{kg}^{-1}$ respectively. Calculation of ECM carbonate chemistry using regressions made with $\mathrm{pH}_{(\mathrm{ECM})}$ data made with boron isotope measurements (Figure 4) and confocal data (supplementary Fig. S3) yielded $\mathrm{DIC}_{(\mathrm{ECM})}$ and $\mathrm{TA}_{(\mathrm{ECM})}$ values of 6979 and $8305 \mu \mathrm{mol} . \mathrm{kg}^{-1}$ respectively. In both cases both parameters were found to be higher than seawater.

Although the presence of Carbon Concentrating Mechanisms (CCMs) has already been highlighted for a large range of species, including marine calcifiers such as corals (Furla et al., 2000), the extent to which corals are able to elevate TA and DIC concentration in their ECM has remained largely unknown. Our results, which indicate that corals have highefficiency CCMs favouring skeleton accretion, agree with the conclusions of the recent study 
of Allison and colleagues (Allison et al., 2014), who used skeletal isotopes to show that corals actively concentrate dissolved inorganic carbon and with the study of Zoccola and colleagues which showed the specific localization of $\mathrm{HCO}_{3}{ }^{-}$transporters in the calcifying cells (Zoccola et al., 2015). However, we note that our estimates of elevated [DIC $\mathrm{ECCM}_{(\mathrm{EC})}$ relative to the surrounding seawater do not agree with estimates of $\left[\mathrm{DIC}_{(\mathrm{ECM})}\right]$ derived from microelectrode measurement of $\left[\mathrm{CO}_{3}{ }^{2-}\right]$ by Cai et al. (2016), who argue that $[\mathrm{DIC}(\mathrm{ECM})]$ is not concentrated above seawater values, although our calculated $\left[\mathrm{CO}_{3}{ }^{2-}\right]$ values are in the same range. An explanation for this discrepancy is that at a given carbonate concentration yalue, differences in $\mathrm{pH}_{(\mathrm{ECM})}$ measurements between studies will give a different DIC concentration (Supplementary Fig. S4). Further experimental work is clearly needed to definitively characterize carbonate chemistry in the ECM.

\subsection{Errors estimation and propagation along the calculation chain}

Results of analysis of errors propagation along the calculation chain are summarized in Table 1. Errors associated with calcification rates measurements have a small influence on the calculated ECM composition. A variation of $3 \%$ around the reference value of $6000 \mu \mathrm{mol} . \mathrm{m}^{-}$ ${ }^{2} \cdot \mathrm{h}^{-1}$ induces changes in $\mathrm{DIC}_{(\mathrm{ECM})}$ and $\mathrm{TA}_{(\mathrm{ECM})}$ lower than 2\% (5971-6179 and 7407-7659 $\mu \mathrm{M}$ for DIC and TA respectively). Errors associated with $\mathrm{pH}_{(\mathrm{ECM})}$ evaluation have a larger influence on the final results. A variation of $0.13 \mathrm{pH}$ unit around the reference value of 8.4 induces changes in $\mathrm{DIC}_{(\mathrm{ECM})}$ and $\mathrm{TA}_{(\mathrm{ECM})}$ between 15 and $27 \%$ (4836-7750 and 6336$9165 \mu \mathrm{M}$ for DIC and TA respectively). It is the combined effect of calcification rate and $\mathrm{pH}_{(\mathrm{ECM})}$ errors that has the greatest influence on the final results. A variation of $\pm 3 \%$ on calcification rate coupled with a variation of \pm 0.13 on $\mathrm{pH}_{(\mathrm{ECM})}$ induces changes between 14 and $29 \%$ in $\mathrm{DIC}_{(\mathrm{ECM})}$ and $\mathrm{TA}_{(\mathrm{ECM})}$ evaluation (4753-7882 and 6231-9319 $\mu \mathrm{M}$ for DIC and 
TA respectively). Note that combined effects of errors amplify the changes in final results in cases ' $\mathrm{G}-3 \%$ and $\mathrm{pH}_{(\mathrm{ECM})}+0.13$ ' and ' $\mathrm{G}+3 \%$ and $\mathrm{pH}_{(\mathrm{ECM})}-0.13$ '. By contrast, in cases ' $\mathrm{G}$ - $3 \%$ and $\mathrm{pH}_{(\mathrm{ECM})}-0.13$ ' and ' $\mathrm{G}+3 \%$ and $\mathrm{pH}_{(\mathrm{ECM})}+0.13$ ', the changes in final results decrease (the two errors compensate).

\subsection{ECM characteristics under seawater acidification}

To assess how coral ECM chemistry behaves under ocean acidification, we evaluated the effects of ocean acidification on the ECM chemical composition using data from a longterm laboratory acidification experiment performed on the tropical coral Stylophora pistillata. Coral colonies were exposed to 4 different acidification conditions during more than 1 year (seawater $\mathrm{pH}=7.2,7.4,7.8$ and 8.0). Under these conditions, declines in calcification rates, associated with changes on skeletal porosity, were reported in this species (Tambutté et al., 2015).

By applying our series of calculations on calcification rates measured during this experiment (varying from $4047 \mu \mathrm{mol} \cdot \mathrm{m}^{-2} \cdot \mathrm{h}^{-1}$ at seawater $\mathrm{pH} 8$ to $3404 \mu \mathrm{mol} \cdot \mathrm{m}^{-2} \cdot \mathrm{h}^{-1}$ at seawater $\mathrm{pH}$ 7.2), we found that $\Omega_{\text {arag.(ECM) }}$ and $\left[\mathrm{CO}_{3}{ }^{2-}\right]_{(\mathrm{ECM})}$ showed a very small reduction with OA in comparison with the changes that occurred in seawater (Fig. 5). While $\Omega_{\text {arag.(SW) }}$ decreased from 3.17 to 0.69 (a $78 \%$ decline) when seawater $\mathrm{pH}$ dropped from 8 to 7.2 , $\Omega_{\text {arag.(ECM) }}$ decreased only from 16.77 to 15.22 , and $\left[\mathrm{CO}_{3}{ }^{2-}\right]_{(\mathrm{ECM})}$ only fell from 1150 to 1043 $\mu$ mol. $\mathrm{kg}^{-1}$ (a 9\% decrease). Under the most acidic treatment ( $\mathrm{pH} 7.2$ ), corals continued to calcify despite under-saturated seawater conditions $\left(\Omega_{\text {arag.(SW) }}<1\right.$, (Tambutté et al., 2015)) and $\Omega_{\text {arag.(ECM) }}$ and $\left[\mathrm{CO}_{3}{ }^{2-}\right]_{(\mathrm{ECM})}$ were both 22.4 times higher than in seawater. This result clearly

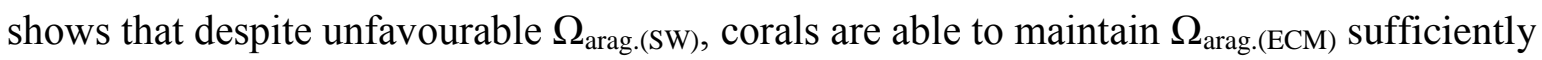
high to allow calcification to proceed. $\left[\mathrm{HCO}_{3}{ }^{-}\right]_{(\mathrm{ECM})}$ gradually increased as seawater $\mathrm{pH}$ was 
reduced, reaching $12806 \mu$ mol. $\mathrm{kg}^{-1}$ for seawater $\mathrm{pH} 7.2$ (e.g 5.2 times higher than seawater). $\left[\mathrm{CO}_{2}\right]_{(\mathrm{ECM})}$ increased with acidification but remained in the same order of magnitude as seawater. $\mathrm{DIC}_{(\mathrm{ECM})}$ and $\mathrm{TA}_{(\mathrm{ECM})}$ increased with declining seawater $\mathrm{pH}$, reaching values 5.3 and 5.8 times higher than in seawater, respectively for DIC and TA, under seawater $\mathrm{pH}$ 7.2.

These results highlight that the ECM in S. pistillata under OA has a higher buffer capacity than under current $\mathrm{pH}$ and allow a quantification of the active biological control of the ECM chemistry by these organisms. CCM may explain the tolerance of S. pistillata to OA. The organic matrix may also be involved in this process since it has been shown that OA induced an up-regulation of organic matrix coding genes (Vidal-Dupiol et al., 2013) and an increase of organic matrix content in the skeleton (Tambutté et al., 2015). Our mathematical framework focuses on physico-chemical aspects of the ECM (i.e. carbonate chemistry) and, in common with previous indirect methods to estimate ECM chemistry, does not describe organic matrix components of the ECM or their effect on calcification. Further research on the properties and role of the organic matrix in corals is needed, before its involvement can be integrated into models. Further research should also address the additional energetic costs associated with calcification under acidification and how those costs might be met by nutrition. It is important to note that, in the OA study used here, coral colonies were fed twice a week with Artemia salina nauplii. Heterotrophy is an important source of nutrition for $S$. pistillata (Houlbrèque et al., 2003), and this may play a significant role during OA by supplying the required energy to achieve the ion transport necessary to sustain high $\Omega_{\text {arag.(ECM) }}$ despite reduced pH (Cohen and Holcomb, 2009; Edmunds, 2011). It is possible that colonies of S. pistillata in the field which don't receive the same level of heterotrophic nutrition would not maintain such a high biological control of the ECM.

The current study explored how ECM composition responds to a range of decreases in seawater $\mathrm{pH}$ that lie beyond those projected to occur this century by the Earth System Models. 
These models forecast a global surface decrease in ocean $\mathrm{pH}$ of 7.8 by 2100 (with the 'business-as-usual' scenario RCP8.5). At pH 7.8 in the OA experiment used in the current study, $\Omega_{\text {arag.(ECM) }}$ and $\left[\mathrm{CO}_{3}{ }^{2-}\right]_{(\mathrm{ECM})}$ were found to be 7.2 times higher than seawater. $\mathrm{DIC}_{(\mathrm{ECM})}$ and $\mathrm{TA}_{(\mathrm{ECM})}$ values were $\sim 4$ times higher than seawater, representing a respective increase of 40-50\% compared to values calculated at $\mathrm{pH} 8$.

The effects of OA on coral ECM chemical composition were synthetized using a Deffeyes diagram (Deffeyes, 1965), in which iso-contours of aragonite saturation state were plotted as a function of TA and DIC (Fig. 6). With the aim of illustrating the biological control of corals on their ECM chemistry, we represented the position of the seawater characteristics in the 4 treatments (white crosses) and the localization of ECM features (white circles) on the same graph. In the OA experiment, the decrease in seawater $\mathrm{pH}$ was associated with an increase in $\mathrm{DIC}_{(\mathrm{SW})}$ but $\mathrm{TA}_{(\mathrm{SW})}$ remained almost constant. Under reduced $\mathrm{pH}$, corals raised both their internal $\mathrm{DIC}_{(\mathrm{ECM})}$ and $\mathrm{TA}_{(\mathrm{ECM})}$. Moreover, the amplitude of changes in $\mathrm{ECM}$ composition was much larger than changes in seawater chemistry. This representation illustrates the buffering capacity resulting from a high biological ECM control in S. pistillata faced with ocean acidification. The 4 points representing ECM compositions under reduced seawater $\mathrm{pH}$ were aligned and nearly followed $\Omega_{\text {arag. }}$ isolines, whereas in seawater, a decline in $\mathrm{pH}$ was related to a drop of $\Omega_{\text {arag. }}$. A decline in $\Omega_{\text {arag.(Sw) }}$ from 3.17 to 0.69 induced a

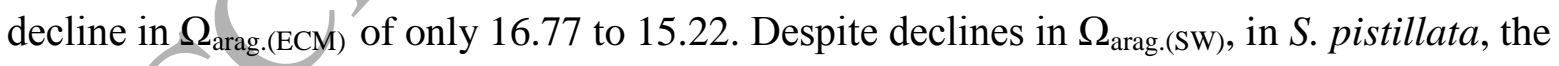
biological regulation of ECM chemistry keeps $\Omega_{\text {arag.(ECM) }}$ almost constant under OA. The representation of ECM chemistry on a Deffeyes diagram gives a visual illustration of the trajectory of changes in ECM composition related to OA.

\section{Conclusions}


This study proposes a mathematical framework to calculate the chemical composition of coral ECM from calcification rates (normalized by the corals' surface area) and seawater characteristics (temperature, salinity, pH). Application of this method on 29 published coral calcification rates enabled us to calculate the range of $\Omega_{\text {arag.(ECM) }}$ and ECM carbonate system ion concentrations. Results showed that corals greatly modify the composition of their ECM in comparison with seawater by concentrating DIC and TA. Under current seawater $\mathrm{pH}$ conditions, corals elevate their $\Omega_{\text {arag.(ECM) }}$ about 5 to 6-fold compared with seawater. $\mathrm{DIC}_{(\mathrm{ECM})}$ and $\mathrm{TA}_{(\mathrm{ECM})}$ were also found on average 3 times higher than seawater. These results illustrate the efficiency of the physiological mechanisms (e.g. ion transport) that control ECM chemistry and therefore drive calcification.

Under ocean acidification, S. pistillata regulates its ECM chemical composition to buffer the negative effects of acidity on the calcification process. These results explain the low sensitivity response of calcification rates to declining seawater $\mathrm{pH}$ in this species and suggest a higher activity of physiological mechanisms involved in the calcification process under OA. This hypothesis is consistent with the conclusions of recent transcriptomic studies which showed an up-regulation of the expression of ion transport genes and organic matrix protein genes under $\mathrm{CO}_{2}$-driven seawater $\mathrm{pH}$ decreases (Moya et al., 2012; Vidal-Dupiol et al., 2013).

The mathematical framework presented in this study to calculate coral ECM chemical characteristics will be useful for both geochemists that need to know how chemical elements behave in the ECM and reefs modellers that need to understand how the chemical composition of the coral ECM varies in response to OA in order to improve their predictions of coral calcification rate in coming decades. As recently pointed out by Jokiel (Jokiel, 2015) and Cyronak et al. (Cyronak et al., 2015), there may be an inconsistency between observations and models of future reef decline due to OA which directly link calcification 
rates to $\Omega_{\text {arag.(SW). }}$ Our results that concern the organism and micro- scale, illustrate the high biological control of the ECM chemical composition under reduced $\mathrm{pH}$, and show the importance of considering the potential of organisms to mitigate the effects of $\mathrm{OA}$ in reef models (Edmunds et al., 2016). It should be noted, however, that corals can greatly vary in their vulnerability to ocean acidification. Of particular note is the study of (Fine and Tchernov, 2007), who observed total disappearance of the skeleton of Oculina patagonica and Madracis pharencis under seawater acidification treatments. If $\mathrm{pH}_{(\mathrm{ECM})}$ data should ever become available for these corals it would be interesting to use our methods to investigate ECM carbonate chemistry is these species.

Furthermore, although our results suggest that S. pistillata can buffer the impact of OA by modifying their ECM chemistry, it has been shown in a recent study that even in corals considered as tolerant to OA, there can be changes in the morphology and in the porosity of skeleton (Tambutté et al., 2015). With more porous skeletons, corals are more vulnerable to bioerosion and damage by physical stressors such as storms. It is also important to keep in mind that corals are also currently threatened by numerous other environmental pressures (global warming, pollution, UV, destructive fishing practices, etc ...). Integrative multispecies studies are needed to evaluate the vulnerability (Beaugrand et al., 2015) of coral reefs to all environmental changes that will be encountered by the end of the century. 


\section{Acknowledgments}

This work was supported by the Centre Scientifique de Monaco research program, funded by the Government of the Principality of Monaco. We acknowledge Jean-Pierre Gattuso and Lina Hansson for the management of the OA-ICC (Ocean Acidification International Coordination Centre) database, a useful tool for data compilation about ocean acidification. We also thank Andrea Gori and Riccardo Rodolfo-Metalpa for interesting discussions and data provided and Dieter Wolf-Gladrow for his helpful answers to our questions about csys.m package.

\section{Additional Information}

Supplementary information accompanies this paper.

\section{Author contributions}

V.R. formulated the idea. V.R., S.T., C.F.P., S.R. and A.A.V. compiled the data. V.R., S.T., C.F.P., A.A.V., E.T. and D.A. analysed the data. P.N. helped in the statistical analyses. All authors discussed the results and contributed to the writing of the paper. 


\section{References}

Al-Horani, F. A., Al-Moghrabi, S. M., de Beer, D., 2003. The mechanism of calcification and its relation to photosynthesis and respiration in the scleractinian coral Galaxea fascicularis. Mar Biol $142,419-426$.

Alekseenko, E., Raybaud, V., Espinasse, B., Carlotti, F., Queguiner, B., Thouvenin, B., Garreau, P., Baklouti, M., 2014. Seasonal dynamics and stoichiometry of the planktonic community in the NW Mediterranean Sea: a 3D modeling approach. Ocean Dynamics 64, 179-207.

Allison, N., Cohen, I., Finch, A. A., Erez, J., Tudhope, A. W., Edinburgh Ion Microprobe, F., 2014. Corals concentrate dissolved inorganic carbon to facilitate calcification. Nat Commun 5, 5741.

Anagnostou, E., Huang, K. F., You, C. F., Sikes, E. L., Sherrell, R. M., 2012. Evaluation of boron isotope ratio as a pH proxy in the deep sea coral Desmophyllum dianthus: Evidence of physiological pH adjustment. Earth and Planetary Science Letters 349-350, 251-260.

Arrhenius, S., 1889. Über die Reaktionsgeschwindigkeit bei der Inversion von Rohrzucker durch Säuren. Zeitschrift für physikalische Chemie 4, 226-248.

Beaugrand, G., Edwards, M., Raybaud, V., Goberville, E., Kirby, R. R., 2015. Future vulnerability of marine biodiversity compared with contemporary and past changes. Nature Clim. Change 5 , 695-701.

Bessat, F., Buigues, D., 2001. Two centuries of variation in coral growth in a massive Porites colony from Moorea (French Polynesia): a response of ocean-atmosphere variability from south central Pacific. Palaeogeography, Palaeoclimatology, Palaeoecology 175.

Burton, E. A., Walter, L. M., 1987. Relative precipitation rates of aragonite and Mg calcite from seawater: Temperature or carbonate ion control? Geology 15, 111-114.

Cai, W.-J., Ma, Y., Hopkinson, B. M., Grottoli, A. G., Warner, M. E., Ding, Q., Hu, X., Yuan, X., Schoepf, $\mathrm{V} ., \mathrm{Xu}, \mathrm{H} ., 2016$. Microelectrode characterization of coral daytime interior $\mathrm{pH}$ and carbonate chemistry. Nature communications 7.

Chan, N. C. S., Connolly, S. R., 2013. Sensitivity of coral calcification to ocean acidification: a metaanalysis. Global Change Biology 19, 282-290.

Cohen, A., Holcomb, M., 2009. Why corals care about ocean acidification: Uncovering the mechanism. Oceanography 22.

Coles, S. L., Jokiel, P. L., 1977. Effects of temperature on photosynthesis and respiration in hermatypic corals. Mar Biol 43, 209-216.

Cyronak, T., Schulz, K. G., Jokiel, P. L., 2015. The Omega myth: what really drives lower calcification rates in an acidifying ocean. ICES J Mar Sc, doi:0.1093/icesjms/fsv075.

Deffeyes, K. S., 1965. Carbonate equilibria: a graphical and algebraic approach. Limnology and Oceanography 10, 412-426.

Dickson, A., Millero, F., 1987. A comparison of the equilibrium constants for the dissociation of carbonic acid in seawater media. Deep Sea Research Part A. Oceanographic Research Papers 34, 1733-1743.

Dickson, A. G., Goyet, C., 1994. Handbook of methods for the analysis of the various parameters of the carbon dioxide system in sea water. publisher not identified.

Dissard, D., Douville, E., Reynaud, S., Juillet-Leclerc, A., Montagna, P., Louvat, P., McCulloch, M., 2012. Light and temperature effects on $\delta 11 \mathrm{~B}$ and $\mathrm{B} / \mathrm{Ca}$ ratios of the zooxanthellate coral Acropora sp.: results from culturing experiments. Biogeosciences 9, 4589-4605.

Edmunds, P. J., 2011. Zooplanktivory ameliorates the effects of ocean acidification on the reef coral Porites spp. Limnol Oceanogr 56, 2402-2410.

Edmunds, P. J., Comeau, S., Lantz, C., Andersson, A., Briggs, C., Cohen, A., Gattuso, J.-P., Grady, J. M., Gross, K., Johnson, M., 2016. Integrating the Effects of Ocean Acidification across Functional Scales on Tropical Coral Reefs. BioScience, biw023.

Fine, M., Tchernov, D., 2007. Scleractinian coral species survive and recover from decalcification. Science 315, 1811. 
Furla, P., Galgani, I., Durand, I., Allemand, D., 2000. Sources and mechanisms of inorganic carbon transport for coral calcification and photosynthesis. J Exp Biol 203, 3445-3457.

Gehlen, M., Séférian, R., Jones, D., Roy, T., Roth, R., Barry, J., Bopp, L., Doney, S. C., Dunne, J. P., Heinze, C., 2014. Projected pH reductions by 2100 might put deep North Atlantic biodiversity at risk. Biogeosciences 11, 6955-6967.

Hendriks, I. E., Duarte, C. M., Olsen, Y. S., Steckbauer, A., Ramajo, L., Moore, T. S., Trotter, J. A., McCulloch, M., 2015. Biological mechanisms supporting adaptation to ocean acidification in coastal ecosystems. Estuarine, Coastal and Shelf Science 152, A1-A8.

Hohn, S., Merico, A., 2012. Modelling coral polyp calcification in relation to ocean acidification. Biogeosciences 9, 4441-4454.

Holcomb, M., Venn, A. A., Tambutte, E., Tambutte, S., Allemand, D., Trotter, J., McCulloch, M., 2014. Coral calcifying fluid $\mathrm{pH}$ dictates response to ocean acidification. Sci Rep 4, 5207.

Hönisch, B., Hemming, N. G., Grottoli, A. G., Amat, A., Hanson, G. N., Bijma, J., 2004. Assessing scleractinian corals as recorders for paleo-pH: Empirical calibration and vital effects. Geochim Cosmochim Acta 68, 3675-3685.

Houlbrèque, F., Tambutté, E., Ferrier-Pagès, C., 2003. Effect of zooplankton availability on the rates of photosynthesis, and tissue and skeletal growth in the scleractinian coral Stylophora pistillata. J Exp Mar Biol Ecol 296, 145-166.

Jokiel, P. L., 2015. Predicting the impact of ocean acidification on coral reefs: evaluating the assumptions involved. ICES J Mar Sc, fsv091, doi:10.1093/icesjms/fsv091.

Jokiel, P. L., Coles, S. L., 1977. Effects of temperature on the mortality and growth of Hawaiian reef corals. Mar Biol 43, 201-208.

Krief, S., Hendy, E. J., M., F., Yam, R., Meibom, A., Foster, G. L., Shemesh, A., 2010. Physiological and isotopic responses of scleractinian corals to ocean acidification. Geochim Cosmochim Ac 74, 4988-5001.

Kühl, M., Cohen, Y., Dalsgaard, T., Jorgensen, B. B., Revsbech, N. P., 1995. Microenvironment and photosynthesis of zooxanthellae in scleractinian corals studied with microsensors for $\mathrm{O} 2, \mathrm{pH}$, and light. Mar Ecol Prog Ser 117, 159-172.

McCulloch, M., Falter, J., Trotter, J., Montagna, P., 2012a. Coral resilience to ocean acidification and global warming through $\mathrm{pH}$ up-regulation. Nature Clim. Change 2, 623-627.

McCulloch, M., Trotter, J., Montagna, P., Falter, J., Dunbar, R., Freiwald, A., Försterra, G., López Correa, M., Maier, C., Rüggeberg, A., Taviani, M., 2012b. Resilience of cold-water scleractinian corals to ocean acidification: Boron isotopic systematics of $\mathrm{pH}$ and saturation state up-regulation. Geochim Cosmochim Ac 87, 21-34.

McNeil, B. I., Matear, R. J., Barnes, D. J., 2004. Coral reef calcification and climate change: The effect of ocean warming. Geophysical Research Letters 31.

Mehrbach, C., Culberson, C., Hawley, J., Pytkowicx, R., 1973. Measurement of the apparent dissociation constants of carbonic acid in seawater at atmospheric pressure. Limnology and Oceanography 18, 897-907.

Moberg, F., Folke, C., 1999. Ecological goods and services of coral reef ecosystems. Ecol. Econ. 29, 215-233.

Moya, A., Huisman, L., Ball, E. E., Hayward, D. C., Grasso, L. C., Chua, C. M., Woo, H. N., Gattuso, J. P., ForÊT, S., Miller, D. J., 2012. Whole Transcriptome Analysis of the Coral Acropora millepora Reveals Complex Responses to CO2-driven Acidification during the Initiation of Calcification. Mol Ecol 21, 2440-2454.

Mucci, A., 1983. The solubility of calcite and aragonite in seawater at various salinities, temperatures, and one atmoshere total pressure. American Journal of Science 283, 780-799.

Mucci, A., Morse, J. W., 1983. The incorporation of Mg 2+ and Sr 2+ into calcite overgrowths: influences of growth rate and solution composition. Geochimica et Cosmochimica Acta 47, 217-233. 
Nakamura, T., Nadaoka, K., Watanabe, A., 2013. A coral polyp model of photosynthesis, respiration and calcification incorporating a transcellular ion transport mechanism. Coral Reefs 32, 779794.

Nisumaa, A.-M., Pesant, S., Bellerby, R. G. J., Dilille, B., Middelburg, J., Orr, J. C., Riebsell, U., Tyrrell, T., Wolf-Gladrow, D., Gattuso, J. P., 2010. Epoca/Eur-Oceans data-mining compilation on the impacts of ocean acidification. Earth System Science Data 3, 109-130.

Porter, J. W., Tougas, J. I., 2001. Reef ecosystems: threats to their biodiversity. In: Levin, S. A., (Ed.), Encyclopedia of Biodiversity, Vol. 5. Academic Press, San Diego, pp. 73-95.

Raybaud, V., Nival, P., Prieur, L., 2011. Short time-scale analysis of the NW Mediterranean ecosystem during summer-autumn transition: A 1D modelling approach. J Mar Syst 84, 1-17.

Reynaud-Vaganay, S., Gattuso, J.-P., Cuif, J.-P., Jaubert, J., Juillet-Leclerc, A., 1999. A novel culture technique for scleractinian corals: application to investigate changes in skeletal $d^{18} 0$ as a function of temperature. Mar Ecol Prog Ser 180, 121-130.

Reynaud, S., Hemming, N. G., Juillet-Leclerc, A., Gattuso, J.-P., 2004. Effect of $p \mathrm{CO}_{2}$ and temperature of the boron isotopic composition of the zooxanthellate coral Acropora sp. Coral Reefs 23, 539-546.

Ries, J. B., 2011. A physicochemical framework for interpreting the biological calcification response to CO2-induced ocean acidification. Geochim Cosmochim Ac 75, 4053-4064.

Rodolfo-Metalpa, R., Richard, C., Allemand, D., Ferrier-Pagès, C., 2006. Growth and photosynthesis of two Mediterranean corals, Cladocora caespitosa and Oculina patagonica, under normal and elevated temperatures. J Exp Biol 209, 4546 - 4556.

Silverman, J., Lazar, B., Erez, J., 2007. Effect of aragonite saturation, temperature, and nutrients on the community calcification rate of a coral reef.J Gephys Res 112, 1-14.

Spalding, M. D., Ravilious, C., Green, E. P., 2001. World atlas of coral reefs. University of California Press.

Sun, W., Jayaraman, S., Chen, W., Persson, K. A., Ceder, G., 2015. Nucleation of metastable aragonite CaCO3 in seawater. Proc Natl Acad Sci USA 112, 3199-204.

Tambutté, E., Venn, A., Holcomb, M., Segonds, N., Techer, N., Zoccola, D., Allemand, D., Tambutté, S., 2015. Morphological plasticity of the coral skeleton under CO2-driven seawater acidification. Nature communications 6:7368.

Tambutté, S., Holcomb, M., Ferrier-Pagès, C., Reynaud, S., Tambutté, E., Zoccola, D., Allemand, D., 2011. Coral biomineralization: From the gene to the environment. J Exp Mar Biol Ecol, 58-78.

Thresher, R. E., Tilbrook, B., Fallon, S., Wilson, N. C., Adkins, J., 2011. Effects of chronic low carbonate saturation levels on the distribution, growth and skeletal chemistry of deep-sea corals and other seamount megabenthos. Marine Ecology Progress Series 442, 87-99.

Trotter, J., Montagna, P., McCulloch, M., Silenzi, S., Reynaud, S., Mortimer, G., Martin, S., FerrierPagès, C., Gattuso, J.-P., Rodolfo-Metalpa, R., 2011. Quantifying the pH 'vital effect' in the temperate zooxanthellate coral Cladocora caespitosa: Validation of the boron seawater $\mathrm{pH}$ proxy. Earth and Planetary Sci. Lett. 303, 163-173.

Venn, A. A., Tambutté, E., Holcomb, M., Allemand, D., Tambutte, S., 2011. Live tissue imaging shows reef corals elevate $\mathrm{pH}$ under their calcifying tissue relative to seawater. PLoS ONE 6, e20013.

Venn, A. A., Tambutté, E., Holcomb, M., Laurent, J., Allemand, D., Tambutté, S., 2013. Impact of seawater acidification on $\mathrm{pH}$ at the tissue-skeleton interface and calcification in reef corals. Proc Natl Acad Sci USA 110, 1634-1639.

Vidal-Dupiol, J., Zoccola, D., Tambutte, E., Grunau, C., Cosseau, C., Smith, K. M., Freitag, M., Dheilly, N. M., Allemand, D., Tambutte, S., 2013. Genes related to ion-transport and energy production are upregulated in response to $\mathrm{CO} 2$-driven $\mathrm{pH}$ decrease in corals: new insights from transcriptome analysis. PLoS ONE 8, e58652.

Zeebe, R. E., Wolf-Gladrow, D., 2001. CO2 in seawater: Equilibrium, kinetics, isotopes. Elsevier Oceanography Series, Amsterdam, The Netherlands. 
Zoccola, D., Ganot, P., Bertucci, A., Caminiti-Segonds, N., Techer, N., Voolstra, C. R., Aranda, M., Tambutte, E., Allemand, D., Casey, J. R., Tambutte, S., 2015. Bicarbonate transporters in corals point towards a key step in the evolution of cnidarian calcification. Sci Rep 5, 9983.

\section{Tables}

Table 1: Results of analysis of errors propagation along the calculation chain. Errors propagation was calculated with $\mathrm{G}=6000 \mu \mathrm{mol} \cdot \mathrm{m}^{-2} \cdot \mathrm{h}^{-1} \pm 3 \%$ and $\mathrm{pH}_{(\mathrm{ECM})}=8.4 \pm 0.13$.

\begin{tabular}{|c|c|c|c|c|c|c|c|c|c|c|}
\hline & $\begin{array}{l}\text { Parameter(s) } \\
\text { modified }\end{array}$ & $\begin{array}{c}\mathrm{G} \\
\left(\mu \mathrm{mol} \cdot \mathrm{m}^{-2} \cdot \mathrm{h}^{-1}\right)\end{array}$ & $\mathrm{pH}_{(\mathrm{ECM})}$ & $\Omega_{\text {arag. }}$ & $\begin{array}{l}\mathrm{CO}_{3}^{2-} \\
(\mu \mathrm{M})\end{array}$ & $\begin{array}{c}\mathrm{HCO}_{3}^{-} \\
(\mu \mathrm{M})\end{array}$ & $\begin{array}{l}\mathrm{CO}_{2} \\
(\mu \mathrm{M})\end{array}$ & $\begin{array}{l}\mathrm{OH}^{-} \\
(\mu \mathrm{M})\end{array}$ & $\begin{array}{l}\text { DIC } \\
(\mu \mathrm{M})\end{array}$ & $\begin{array}{l}\text { ALK } \\
(\mu \mathrm{M})\end{array}$ \\
\hline $\begin{array}{l}\text { Reference } \\
\text { values }\end{array}$ & - & 6000 & 8.40 & 20.98 & 1295.09 & & 13.35 & 15.23 & 6075.51 & 7533.99 \\
\hline \multirow{2}{*}{$\begin{array}{l}\text { Errors on G } \\
\quad \text { only }\end{array}$} & $\mathrm{G}-3 \%$ & 5820 & 8.40 & 20.62 & 1272.78 & 4684.95 & 13.12 & 15.23 & 5970.84 & 7407.24 \\
\hline & $\mathrm{G}+3 \%$ & 6180 & 8.40 & 21.34 & 1317.14 & 4848.22 & 13.57 & 15.23 & 6178.93 & 7659.22 \\
\hline \multirow{2}{*}{$\begin{array}{c}\text { Errors on } \\
\mathrm{pH}_{(\mathrm{ECM})} \text { only }\end{array}$} & $\mathrm{pH}_{(\mathrm{ECM})}-0.13$ & 6000 & 8.27 & 20.98 & 1295.09 & 6430.60 & 24.29 & 11.29 & 7749.98 & 9165.17 \\
\hline & $\mathrm{pH}_{(\mathrm{ECM})}+0.13$ & 6000 & 8.53 & 20.98 & 1295.09 & 3533.88 & 7.34 & 20.55 & 4836.31 & 6336.48 \\
\hline \multirow[t]{4}{*}{$\begin{array}{l}\text { Errors on both } \\
\mathrm{G} \text { and } \mathrm{pH}_{(\mathrm{ECM})}\end{array}$} & $\begin{array}{c}\mathrm{G}-3 \% \text { and } \\
\mathrm{pH}_{(\mathrm{ECM})}+0.13\end{array}$ & 5820 & & 20.62 & 1272.78 & 3473.00 & 7.21 & 20.55 & 4752.99 & 6230.98 \\
\hline & $\begin{array}{c}\mathrm{G}-3 \% \text { and } \\
\mathrm{pH}_{(\mathrm{ECM})}-0.13\end{array}$ & & & 20.62 & 1272.78 & 6319.82 & 23.87 & 11.29 & 7616.47 & 9009.76 \\
\hline & $\begin{array}{c}\mathrm{G}+3 \% \text { and } \\
\mathrm{pH}_{(\mathrm{ECM})}+0.13\end{array}$ & & 8.53 & 21.34 & 1317.14 & 3594.03 & 7.46 & 20.55 & 4918.63 & 6440.72 \\
\hline & $\begin{array}{c}\mathrm{G}+3 \% \text { and } \\
\mathrm{pH}_{(\mathrm{ECM})}-0.13\end{array}$ & 6180 & 8.27 & 21.34 & 1317.14 & 6540.06 & 24.70 & 11.29 & 7881.90 & 9318.72 \\
\hline
\end{tabular}




\section{Figure legends}

Figure 1. Scheme summarising the different steps taken to calculate the carbonate chemistry composition of the coral Extracellular Calcifying Medium (ECM) from calcification rate and seawater characteristics. See Methods for equation numbers.

Figure 2. Relationships between ECM pH and seawater $\mathrm{pH}$ for five different coral species.

Data were retrieved from the literature. Two regressions are calculated for Stylophora pistillata, one for $\mathrm{pH}$ derived from boron isotope measurements and one for $\mathrm{pH}_{(\mathrm{ECM})}$ by confocal.

Figure 3. (A) Aragonite saturation states (colorbar) in the coral Extracellular Calcifying $\operatorname{Medium}\left(\Omega_{\text {arag.(ECM) }}\right)$ as a function of calcification rates $\left(\mu \mathrm{mol} \cdot \mathrm{m}^{-2} \cdot \mathrm{h}^{-1}\right)$ and seawater temperatures $\left({ }^{\circ} \mathrm{C}\right) . \Omega_{\text {arag.(ECM) }}$ was calculated with equation (6) from the 29 calcification rates considered in this study (see Methods). Numbers correspond to publications numbers listed in Supplementary Table S1. The grey dashed isoline of $\Omega_{\text {arag. }}=18$ represents the critical supersaturation value necessary to initiate synthetic aragonite nucleation (Sun et al., 2015). (B) Frequency distribution of the values of aragonite saturation state in the ECM represented on the upper panel. (C) Relationship between coral $\Omega_{\text {arag.(ECM) }}$ and seawater temperature $\left({ }^{\circ} \mathrm{C}\right)$. Linear regression is significant $\left(\mathrm{r}^{2}=0.56, \mathrm{n}=29, \mathrm{p}<0.05\right)$. The background colorbar indicates the corresponding calcification rates calculated from equation (3) (see Methods).

Figure 4. Comparison of ion concentrations (in $\mu \mathrm{mol} . \mathrm{kg}^{-1}$ ) of the carbonate system in the Extracellular Calcifying Medium (ECM) and in seawater. For ECM, means and standard deviations (error bars) were based on the 29 studies analysed here (see supplementary Table S1). SW characteristics were calculated using the carbonate chemistry package "csys.m" (Zeebe and Wolf-Gladrow, 2001), from seawater $\mathrm{pH}=8.1$ and $[\mathrm{DIC}]_{(\mathrm{SW})}=2000 \mu \mathrm{mol} . \mathrm{kg}^{-1}$ and 
using constants from Mehrbach et al. (Mehrbach et al., 1973) as refit by Dickson and Millero (Dickson and Millero, 1987).

Figure 5. Impact of ocean acidification on calcification rates and ECM chemical characteristics in S. pistillata. $\Omega_{\text {arag.(ECM) }}$ and carbonate system ion concentrations were calculated for seawater $\mathrm{pH} 7.2,7.4,7.8$ and 8.0 Blue horizontal lines denote seawater chemical conditions for each $\mathrm{pH}$ treatment, calculated with "csys.m" routine from seawater pH and TA measured during the experiment (Tambutté et al., 2015), using constants from Mehrbach et al. (Mehrbach et al., 1973) as refit by Dickson and Millero (Dickson and Millero, 1987).

Figure 6. DIC-TA Deffeyes diagram (Deffeyes, 1965) showing the effect of Ocean Acidification (OA) on the ECM chemical composition of S. pistillata. Iso-contours of aragonite saturation state are plotted as a function of TA and DIC (at temperature $25^{\circ} \mathrm{C}$ and salinity 38, with constants from Mehrbach et al. (Mehrbach et al., 1973) as refit by Dickson and Millero (Dickson and Millero, 1987)). White crosses show the position of seawater characteristics in the $4 \mathrm{pH}$ treatments of the acidification experiment (see Methods). White circles show the position of ECM chemical composition for each $\mathrm{pH}$ treatment. 


\section{Figure 1}

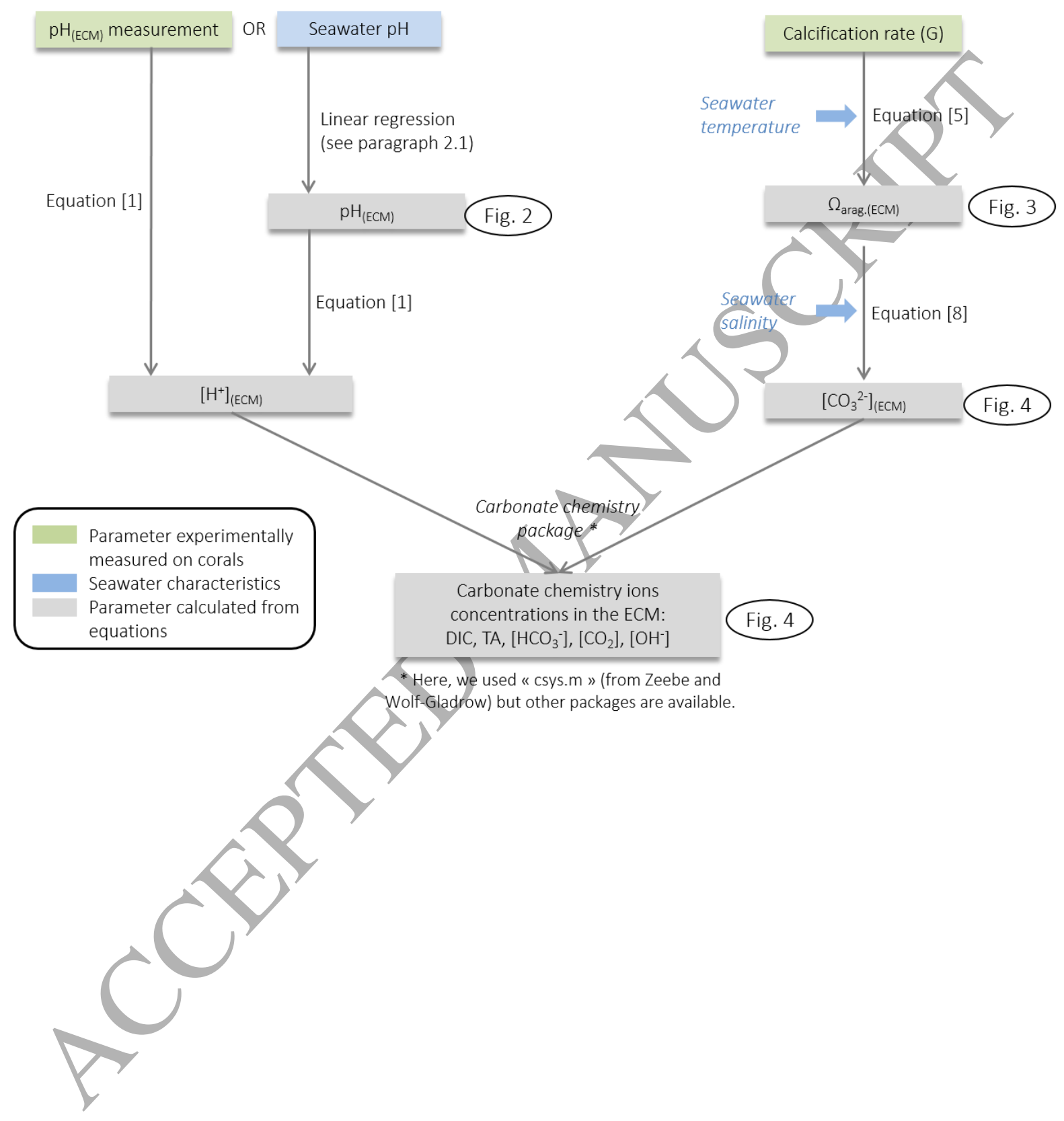


Figure 2

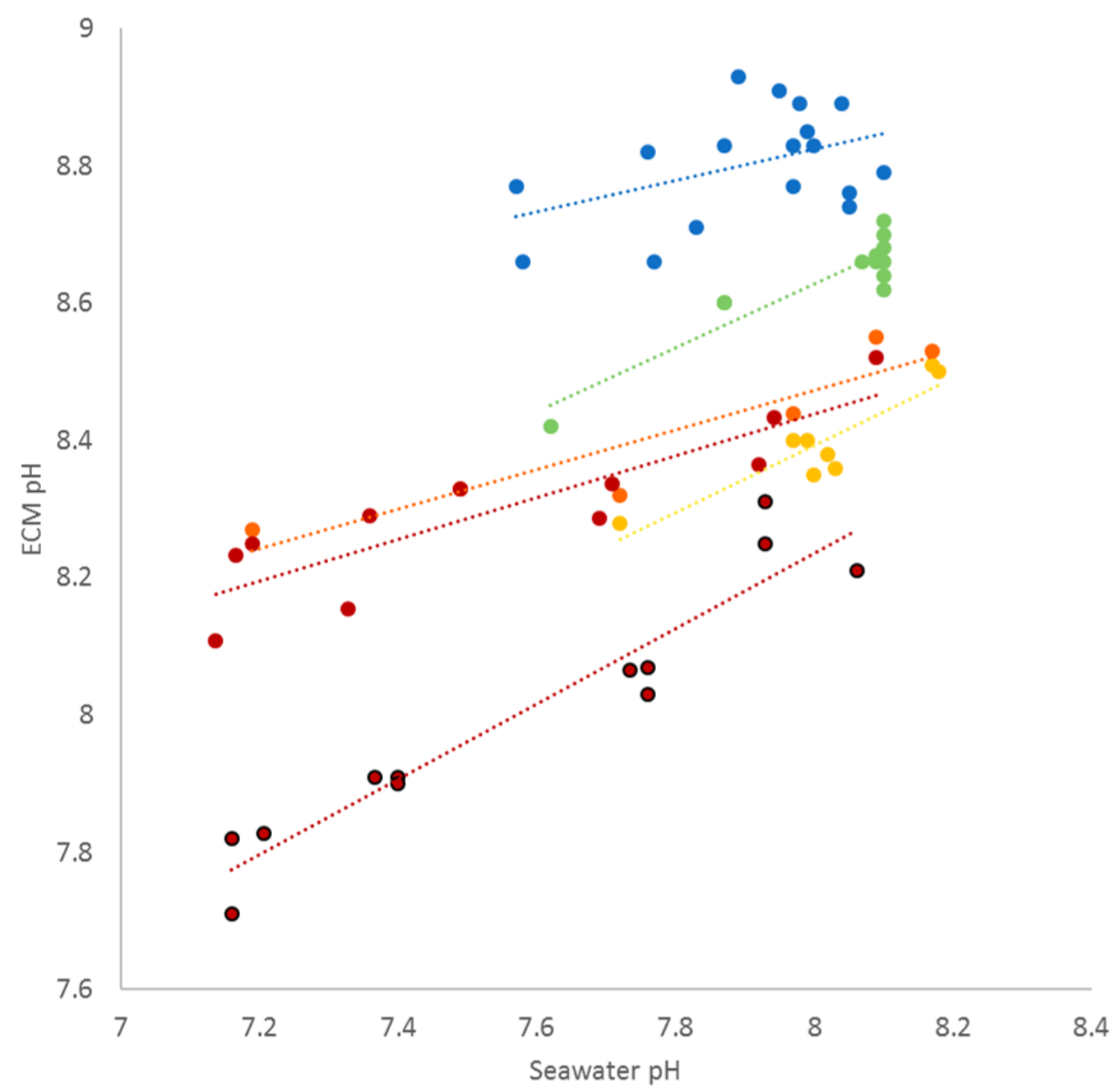

- Desmophyllum dianthus (Anagnostou et al., 2012; McCulloch et al, 2012) y=0.23x+7.00, $\mathrm{r}^{2}=0.19$

- Cladocora caespitosa (Trotter et al., 2011) y $=0.46 x+4.91, r^{2}=0.84$

- Acropora spp. (Trotter et al., 2011; Dissard et al., 2012) y $=0.49 x+4.49, r^{2}=0.82$

- Porites spp. (Trotter et al., 2011) y =0.29x $+6.17, \mathrm{r}^{2}=0.86$

- Stylophora pistillata, B-isotopes (Trotter et al., 2011; Holcomb et al., 2014) y =0.30x + 6.00, $r^{2}=0.78$

- Stylophora pistillata, confocal microscopy (Venn et al., 2013; Holcomb et al., 2014) y =0.55x $+3.84, r^{2}=0.91$ 
Figure 3

A

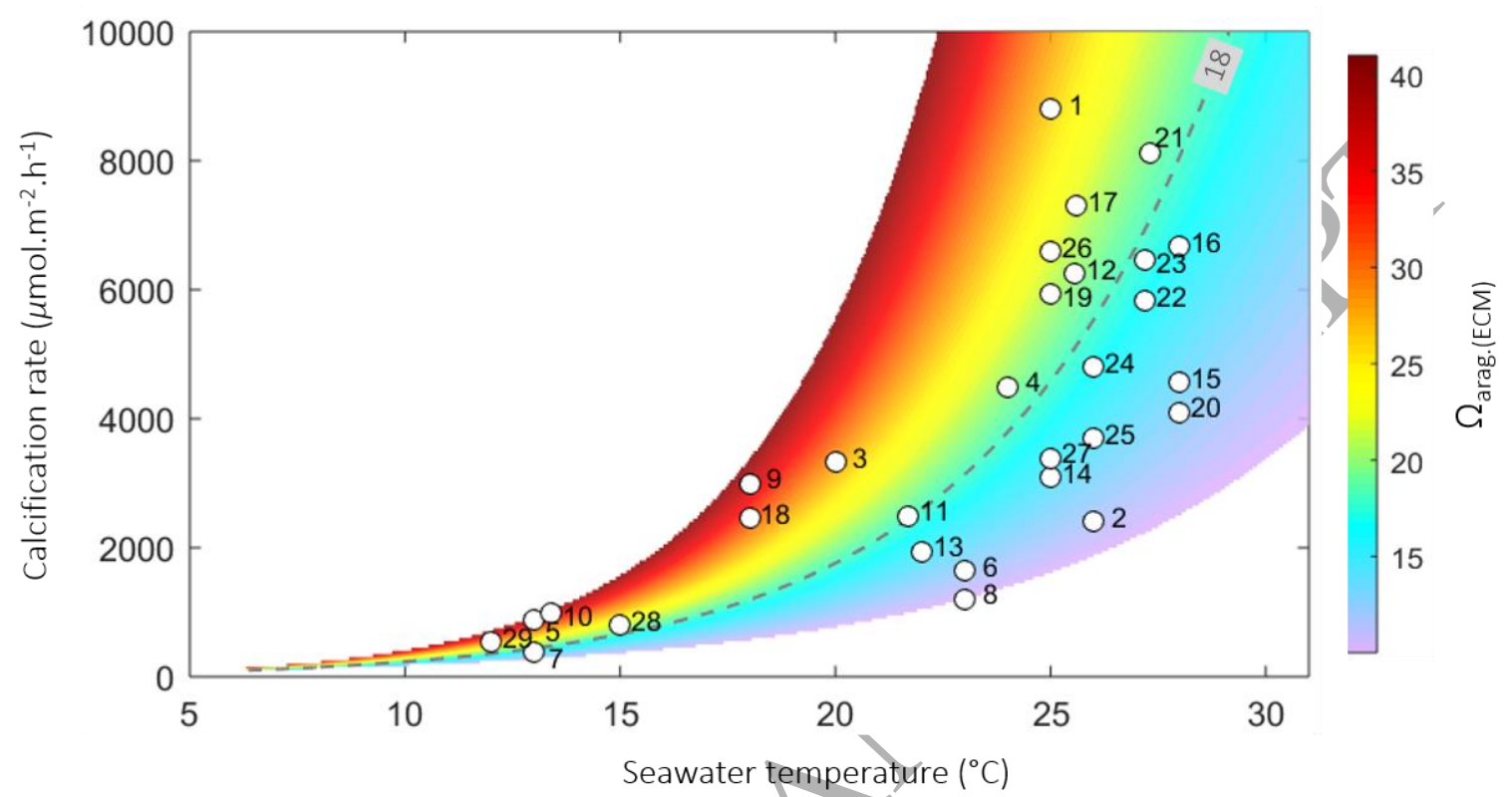

B

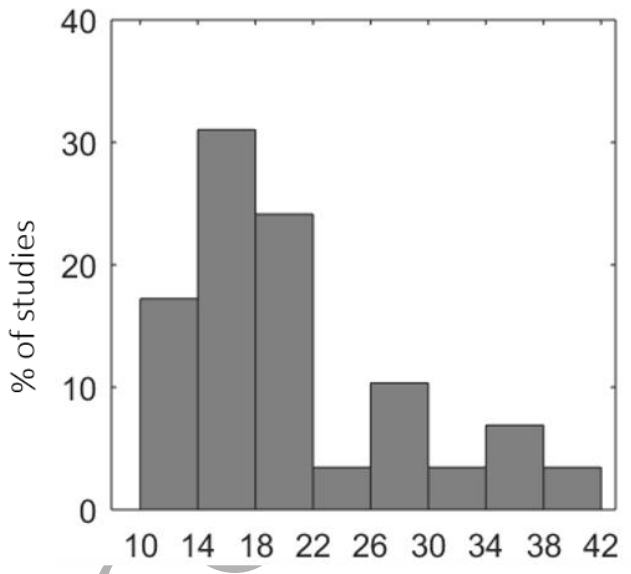

c

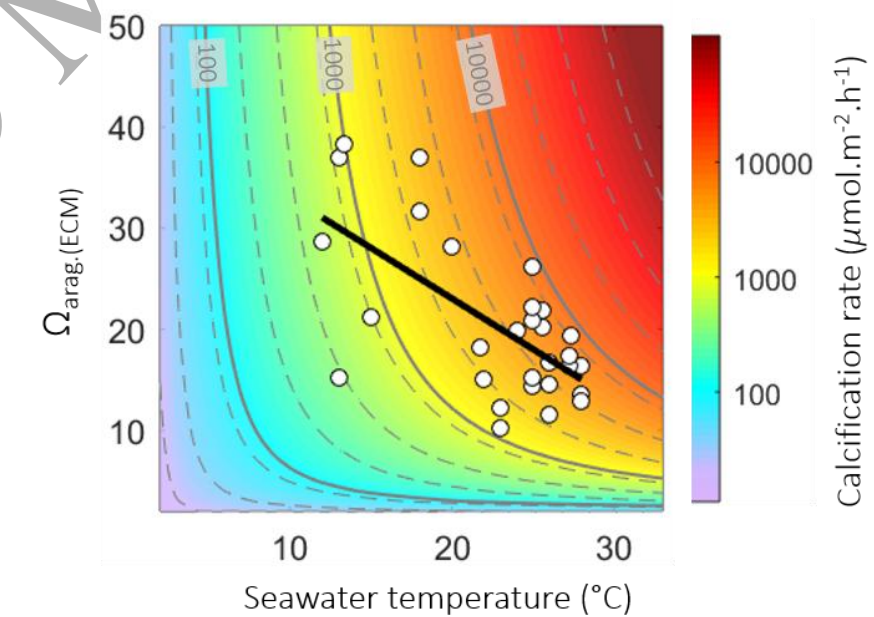


Figure 4
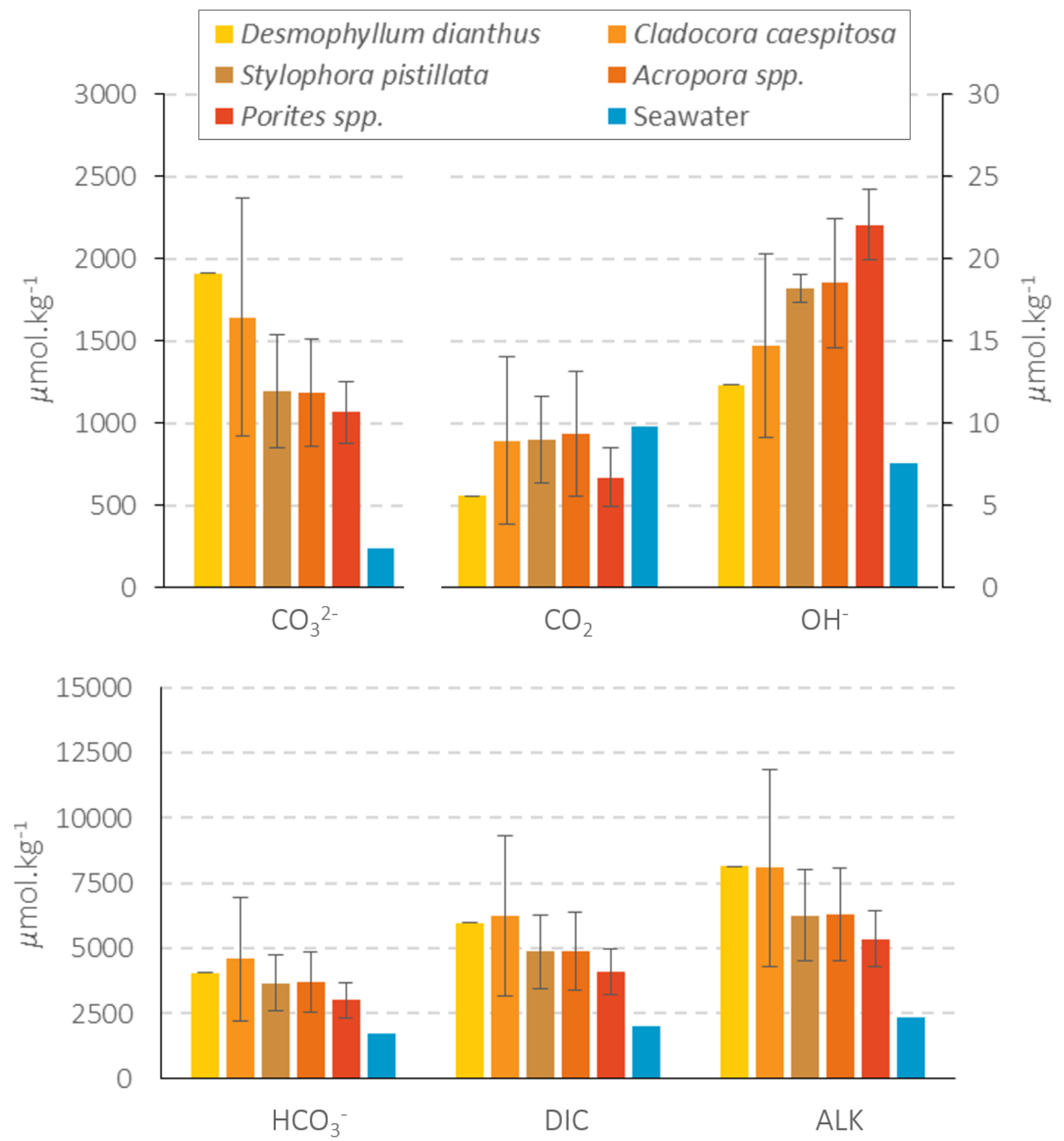
Figure 5
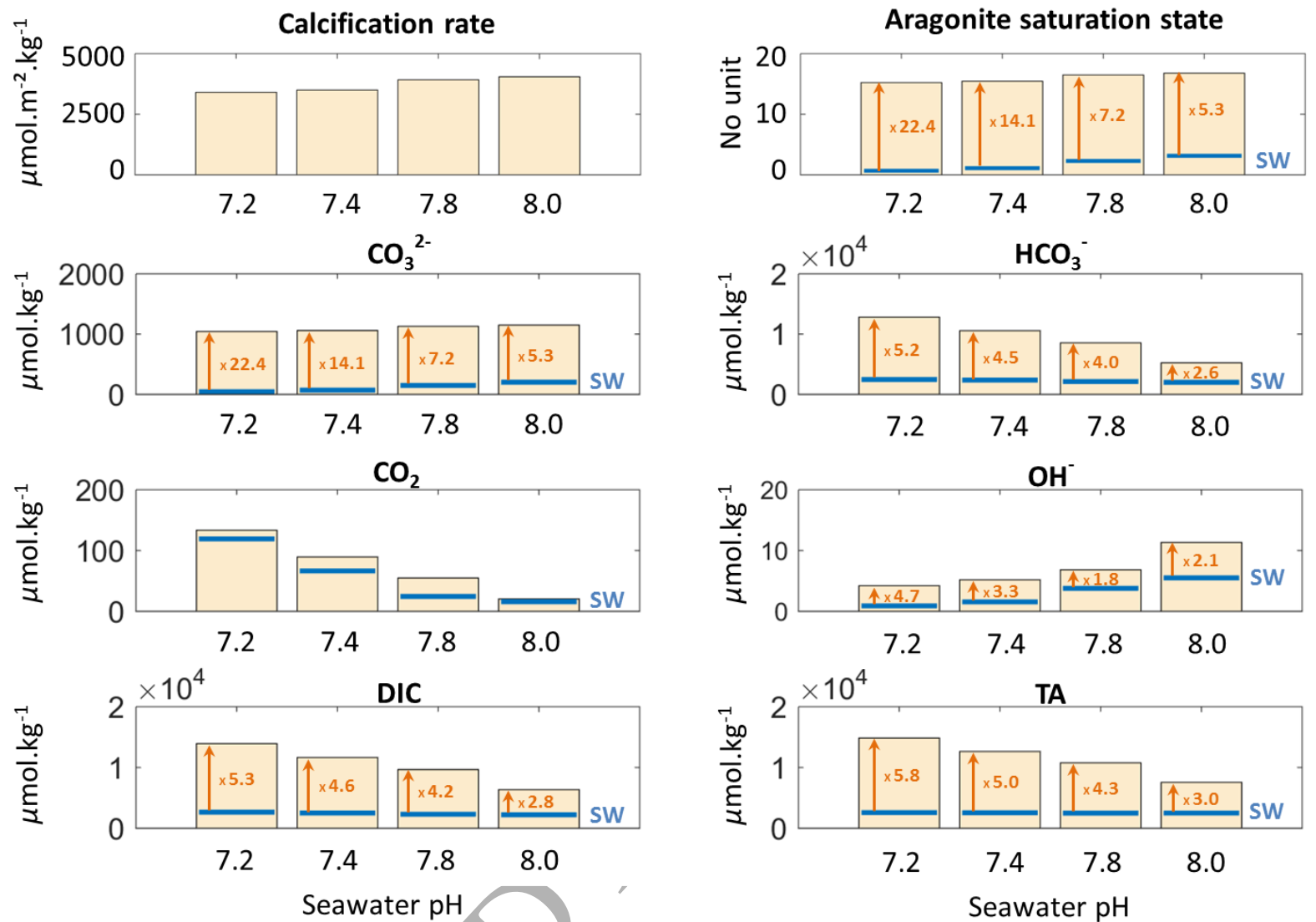
Figure 6

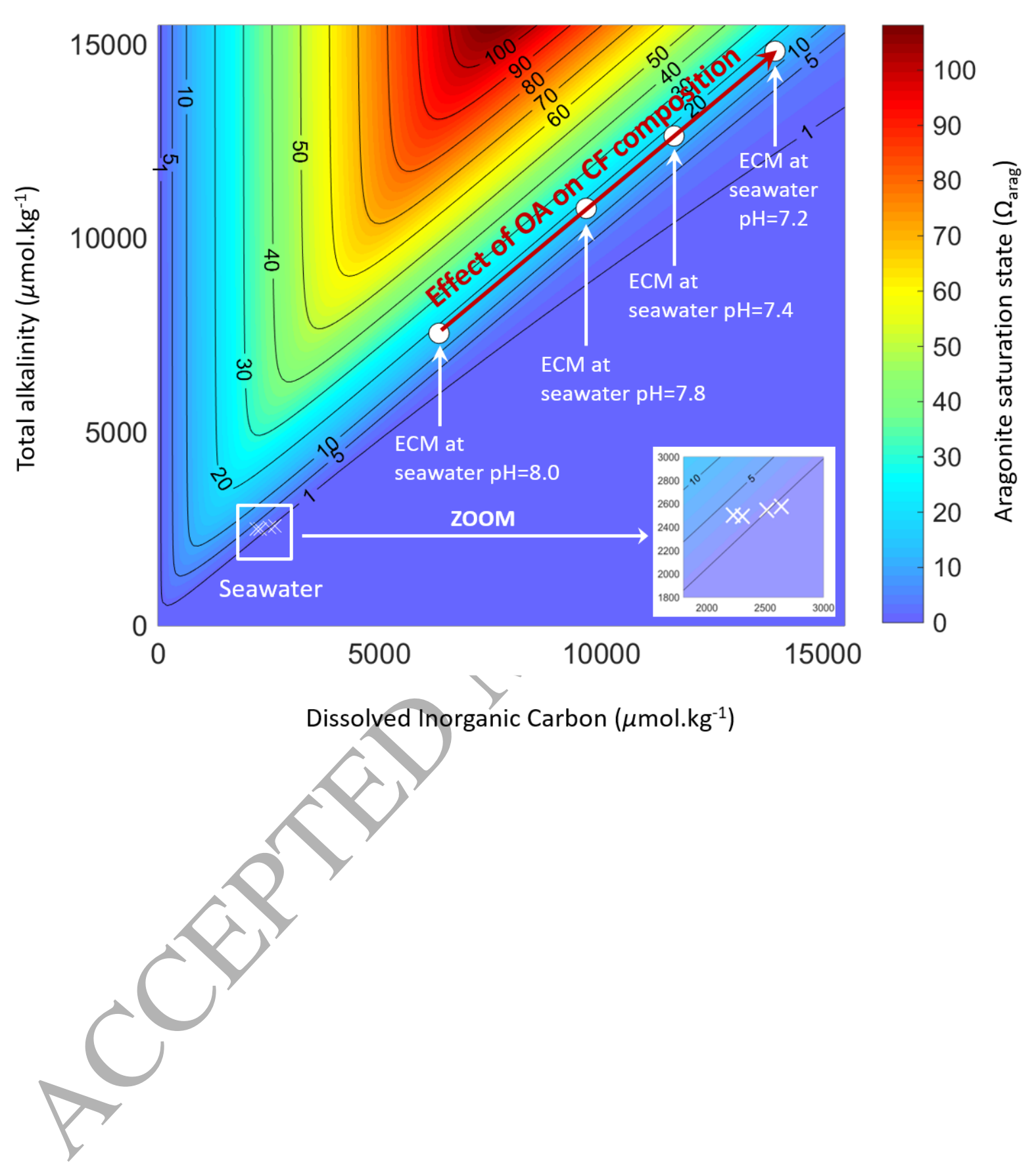

